\title{
Kepastian Hukum Nominee Agreement Kepemilikan Saham Perseroan Terbatas
}

\author{
Lucky Suryo Wicaksono \\ Fakultas Hukum Universitas Islam Indonesia \\ Jln. Tamansiswa 158 Yogyakarta \\ luckywicaksono@rocketmail.com
}

\begin{abstract}
This research discusses the establishment of Nomine Agreement especially in share ownership of Limited Company as well as the position of Nomine Agreement in Indonesian legal system. This was a normative research. The legal references were collected by conducting library research and document study. The findings show that first, the establishment of nominee agreement practically can be categorized into direct and indirect establishment of nominee agreement. Second, the existence of nominee agreement in the legal system in Indonesia has actually been prohibited in Article 33 point (1) and (2) of Law of Capital Investment. The fact that there is no strict prohibition in the Law of Limited Company concerning nominee shareholder prohibition has made nominee agreement develop well by establishing indirect nominee agreement and it is difficult to notice and prove such agreement.
\end{abstract}

Keywords: Nominee agreement, limited companylegal certainty.

\begin{abstract}
Abstrak
Penelitian ini mengkaji pembentukan Nomine Agreement khususnya dalam kepemilikan saham Perseroan Terbatas serta kedudukan Nomine Agreement tersebut dalam sistem hukum di Indonesia. Jenis penelitian yang digunakan adalah penelitian normatif. Bahan-bahan hukum dikumpulkan dengan studi kepustakaan dan studi dokumen. Hasil penelitian menyimpulkan bahwa pertama, pembentukan nominee agreement dalam prakteknya dapat dikategorikan menjadi pembentukan perjanjian nominee langsung dan pembentukan perjanjian nomine tidak langsung. Kedua, kedudukan nominee agreement dalam aturan hukum di Indonesia sebenarnya telah dilarang eksistensinya dalam Pasal 33 ayat (1) dan (2) UU Penanaman Modal. Tidak adanya pelarangan yang tegas dalam UU Perseroan Terbatas tentang pelarangan nominee shareholder membuat praktek nominee agreement berkembang dengan pembentukan nominee tidak langsung nominee agreement tersebut sulit untuk diketahui dan dibuktikan.
\end{abstract}

Kata Kunci: Nominee agreement, perseroan terbatas, kepastian hukum. 


\section{Pendahuluan}

Indonesia merupakan negara berkembang yang memiliki potensi besar sehingga banyak investor lokal maupun asing yang berinvestasi di Indonesia. ${ }^{1}$ Ada beberapa faktor penting yang menjadikan perkembangan iklim investasi di Indonesia sebagai tujuan investor, yaitu: ${ }^{2} 1$. adanya peraturan atau kebijaksanaan yang mendukung investor asing menanamkan modal di Indonesia; 2. tenaga kerja yang besar dengan upah yang relatif rendah; 3. pasar produksi yang luas karena jumlah penduduk Indonesia yang besar; 4. sumber kekayaan alam yang tersedia; 5. stabilitas politik; 6. adanya kepastian hukum dan konsistensi peraturan dan penerapannya.

Pemodal asing yang tertarik melakukan direct investment di Indonesia karena terdapatnya beberapa keuntungan tersebut diatas terbentur oleh aturan negative list investment yang tertuang dalam Peraturan Presiden Republik Indonesia Nomor 39 Tahun 2014 tentang Daftar Bidang Usaha yang Tertutup dan Bidang Usaha yang Terbuka dengan Persyaratan di Bidang Penanaman Modal. Pemerintah, dalam hal ini Badan Koordinasi Penanaman Modal melarang pemodal asing melakukan investasi dengan tujuan untuk memberikan perlindungan terhadap kehidupan masyarakat Indonesia. Beberapa bidang usaha yang termasuk negative list investment antara lain produksi senjata, mesiu, alat peledak, peralatan perang, dan sebagainya.

Konsep nominee atau kadang disebut konsep trust ${ }^{3}$ tidak dikenal dalam sistem hukum civil law yang berlaku di Indonesia. Trusts yang pada mulanya dikatakan khas tradisi hukum common law, kepemilikan secara absolut dipecah menjadi kepemilikan yang terdaftar dalam hukum atau disebut dengan legal owner dan kepemilikan secara kemanfaatan atau kenikmatan dari benda atau disebut beneficial owner. ${ }^{4}$ Konsep nominee pada awalnya hanya terdapat pada sistem hukum common law. Seiring dengan arus investasi, pada sekitar 90-an di Indonesia mulai mengenal konsep nominee dan sering digunakan dalam beberapa transaksi hukum.

${ }^{1}$ Sujud Margono, Hukum Investasi Asing di Indonesia, Novindo Pustaka Mandiri, Jakarta, 2008, hlm. 2.

2 Nindyo Pramono, Bunga Rampai Hukum Bisnis Aktual, Citra Aditya Bakti, Bandung, 2006, hlm 173.

3 The right, enforceable solely in equity, to the beneficial enjoyment of property to wich another person holds the legal title; a property interest held by one person (the trustee) at the request of another (the settlor) for a benefit of a third party (the beneficiary). For a trust to be valid, it must include a specific property, reflect the settlor's interest, and be created for a lanful purpose, sebagai mana dikutip dalam Bryan A. Gardner, “Black's Law Dictionary”, 7th ed., St. Paul, Minnesota: West Group, 1999, hlm. 1513.

4 Gunawan Widjaja, "Pentingnya Pengaturan Trust dalam Institusi di luar Pasar Modal", Ed.18, Buletin Himpunan Konsultan Hukum Pasar Modal, Jakarta, 2013, hlm 7. 
Pemodal asing pada umumnya memilih perseroan terbatas ${ }^{5}$, sebagai bentuk dari badan hukum untuk menjalankan kegiatan investasinya di Indonesia secara langsung atau direct investment. Pendirian perseroan terbatas menurut UndangUndang Nomor 40 Tahun 2007 tentang Perseroan Terbatas, untuk selanjutnya disebut "UUPT", Pasal 7 ayat (1), dapat dilakukan oleh 2 orang atau lebih. 6 Pada bagian penjelasan dari UUPT Pasal 7 ayat (1), yang dimaksud orang adalah perseorangan, baik warga Negara Indonesia maupun asing atau badan hukum Indonesia atau asing. Syarat mendirikan perseroan terbatas melalui perjanjian yang menyebabkan pendirian perseroan terbatas harus dilakukan oleh 2 orang atau lebih sebagai pemegang saham, karena tidak mungkin satu orang mengadakan perjanjian dengan dirinya sendiri. Syarat pendirian perseroan terbatas dengan 2 (dua) orang atau lebih ini juga memicu timbulnya nominee shareholder, dimana pada umumnya pemodal asing ingin menguasai perseroan terbatas secara tidak terbatas.

Dalam nominee agreement, keberadaan seseorang atau suatu pihak tertentu (nominee) yang dijadikan sebagai pemegang saham atau lebih tepatnya pemilik terdaftar dari sejumlah lembar saham tertentu, sedangkan beneficiary mendapatkan manfaat dari saham tersebut. Tujuan dari adanya nominee agreement ini dimaksudkan dalam rangka menyembunyikan kepemilikan saham beneficiary terhadap masyarakat umum serta menghilangkan hubungan terafiliasi antara satu perusahaan dengan perusahaan lainnya yang sudah ada atau didirikan lebih dahulu.

Dengan adanya pembatasan-pembatasan yang ditetapkan oleh pemerintah sebagaimana tertuang dalam suatu ketentuan peraturan perundang-undangan menyebabkan individu tertentu mencari jalan keluar dengan melahirkan konsep-

${ }^{5}$ Lihat I.G. Rai Widjaya, Hukum Perusahaan (Undang-Undang dan Peraturan Pelaksana Undang-Undang di Bidang Usaha), Kesaint Blanc, Bekasi, 2005, hlm. 1, dikatakan, "Perseroan Terbatas atau PT merupakan sebutan yang sudah di Indonesiakan yang sebenarnya berasal dari sebutan NV atau Naamloze Vennootschap. Lihat juga C.S.T. Kansil, dkk, 2010, "Kamus Istilah Aneka Hukum”, Jala Permata, Jakarta, hlm. 97, dikatakan, "Perseroan adalah bentuk kerja sama untuk menjalankan suatu perusahaan, biasanya dengan mengeluarkan sero (saham)." Lihat juga Sulchan Yasin, "Kamus Lengkap Bahasa Indonesia”, CV. Putra Karya, hlm. 288, dikatakan, "Perseroan adalah persekutuan dagang." Bandingkan dengan Anonim, 2003, Oxford Learners Pocket Dictionary, Third Edition, Oxford University Press, Oxford, hlm. 250, "Limited company (in Britain) is a company whose owners only have to pay a limited amounts of its debts". (Perusahaan terbatas (dalam pengertian Britain) adalah sebuah perusahaan yang para pemiliknya hanya diwajibkan untuk membayar sejumlah yang terbatas atas hutang perusahaannya.)" Bandingkan dengan P.P.S. Gogna, 2009, A Textbook of Company Law, Ram Nagar, S. Chand \& Company Ltd., New Delhi, hlm. 9, dikatakan, "The term 'company' may be defined as a group of persons associated together to achieve some common objective. This, however, is not the legal definition. In legal sense, a company means an association of persons incorporated under the existing law of a country.

${ }^{6}$ Undang-Undang tentang Perseroan Terbatas, UU No. 40 Tahun 2007, LN No. 106 Tahun 2007, TLN No. 4756. Ps.7 ayat (1) 
konsep baru, antara lain konsep nominee. Hal tersebut menjadi salah satu alasan yang mendasari penggunaan konsep nominee dalam sistem hukum di Indonesia, peneliti dapat menemukan beberapa transaksi hukum yang menggunakan konsep nominee, antara lain dalam kepemilikan saham oleh pihak asing, kepemilikan tanah oleh warga negara asing, serta pengelolaan perusahaan yang dilakukan oleh direktur nominee (shadow director). ${ }^{7}$

Beberapa transaksi hukum yang menggunakan konsep-konsep nominee di Indonesia, yang paling tegas melarang terdapat di Pasal 33 ayat (1) Undang-Undang Nomor 25 Tahun 2007 tentang Penanaman Modal, untuk selanjutnya disebut "UUPM", ditegaskan bahwa "penanaman modal dalam negeri dan penanaman modal asing yang melakukan penanaman modal dalam bentuk perseroan terbatas dilarang membuat perjanjian dan/atau pernyataan yang menegaskan bahwa kepemilikan saham dalam perseroan terbatas untuk dan atas nama orang lain." ${ }^{8}$ Untuk menghindari terjadinya perseroan yang secara normatif dimiliki seseorang, tetapi secara materi atau substansi pemilik perseroan tersebut adalah orang lain.

Larangan untuk membuat perjanjian yang menyatakan bahwa kepemilikan saham dalam perseroan terbatas untuk dan atas nama orang lain ditegaskan dalam Pasal 33 ayat (1) UUPM. Apabila dilakukan, maka akan berakibat perjanjian dan/atau pernyataan itu menjadi batal demi hukum sebagaimana disebutkan pada Pasal 33 ayat (2) UUPM. Menjadi pertanyaan ketika tidak dibuat perjanjian yang secara eksplisit menyatakan bahwa kepemilikan saham dalam perseroan untuk dan atas nama orang lain, namun dibuat sebuah skema dengan tujuan kepemilikan saham untuk dan atas nama orang lain.

\section{Rumusan Masalah}

Berdasarkan latar belakang permasalahan yang telah diuraikan di atas, maka dapat dirumuskan permasalahan sebagai berikut: pertama, bagaimanakah pembentukan nominee agreement kepemilikan saham perseroan terbatas yang

7 Ahmad Yani \& Gunawan Widjaja, Op. Cit, hlm. 179.

${ }^{8}$ Undang-Undang tentang Penanaman Modal, UU No. 25 Tahun 2007, LN No. 101 Tahun 2007, TLN No. 4724. Penjelasan Ps.33 ayat (1) 
digunakan di Indonesia? Kedua, bagaimana kedudukan nominee agreement di dalam aturan hukum Indonesia?

\section{Tujuan Penelitian}

Penelitian ini bertujuan untuk mengetahui: pertama, pembentukan nominee agreement kepemilikan saham perseroan terbatas di Indonesia. Kedua, menganalisis kedudukan nominee agreement di dalam aturan hukum Indonesia.

\section{Metode Penelitian}

Penelitian ini merupakan penelitian yang bersifat yuridis normatif, yaitu mengacu pada norma hukum yang terdapat dalam peraturan perundangundangan dan norma-norma yang berlaku dan mengikat masyarakat. Penelitian yuridis normatif didasarkan pada data sekunder sebagai data kepustakaan dengan menggunakan metode berpikir deduktif ${ }^{9}$ dan kriterium kebenaran koheren. ${ }^{10}$

\section{Hasil Penelitian dan Pembahasan}

\section{Pembentukan Nominee Agreement Kepemilikan Saham Perseroan Terbatas}

Secara umum, nominee dapat diartikan sebagai berikut: a. one who has been nominated to an office or for a candidacy; or $b$. a person organization in whose name a security is registered though true ownership is held by another party. ${ }^{11}$

Definisi lain yang diberikan oleh kamus dalam hubungannya dengan suatu transaksi bisnis yang menggunakan konsep nominee adalah "person or firm into whose name securities or other properties are transferred in order to facilitate transactions, while

\footnotetext{
${ }^{9}$ Cara berpikir deduktif adalah cara berpikir yang dalam penarikan kesimpulan yang ditarik dari sesuatu yang sifatnya umum yang sudah dibuktikan bahwa dia benar dan kesimpulan itu ditujukan untuk sesuatu yang sifatnya khusus, lihat lebih lanjut dalam Sedarmayanti \& Syarifudin Hidayat. Metodologi Penelitian, Mandar Maju, Bandung, 2002, hlm. 23.

${ }^{10}$ Kebenaran koheren yaitu suatu pengetahuan, teori, pernyataan, proposisi, atau hipotesis dianggap benar kalau sejalan dengan pengetahuan, teori, pernyataan, proposisi, atau hipotesis lainnya, yaitu kalau proposisi itu meneguhkan dan konsisten dengan proposisi sebelumnya yang dianggap benar. Lihat lebih lanjut dalam A. Sonny Keraf \&Mikhael Dua, 2001, Ilmu Pengetahuan, Sebuah Tinjauan Filosofis, Yogyakarta, hlm. 68.

11<http:// wmw.thefreedictionary.com/ nominee $>$, diakses tanggal 03 November 2015.
} 
leaving the customer as the actual owner."12 Berdasarkan pengertian-pengertian di atas, dapat ditarik pengertian nominee sebagai suatu pihak yang ditunjuk oleh pihak lain untuk bertindak mewakili untuk dan atas nama pihak yang menunjuk nominee tersebut.

Pengertian nominee menurut Black's Law Dictionary adalah:

"1. A person who proposed for an office, membership, award or like title, or status. An individual seeking nomination, election or appointment is a candidate. A candidate for election becomes a nominee after being formally nominated. 2. A person designated to act in place of another usually in a very limited way. 3. A party who holds bare legal title for the benefit of others or who receives and distributes funds for the benefit of others". ${ }^{13}$

Selanjutnya nominee trust adalah:

"1. A trust which the beneficiaries have the power to direct the trustee's actions regarding the trust property. 2. An arrangement for holding title to real property under which one or more persons or corporations, under a written declaration of trust, declare that they will hold any property that they acquire as trustees for one or more undisclosed beneficiarie. Also termed realty trust". ${ }^{14}$

Realty trust adalah nominal trust dan nominal trust ${ }^{15}$ adalah suatu passive trust ${ }^{16}$ yang mempunyai definisi " $A$ trust which he trustee has no duty other than to transfer the property to the beneficiary". ${ }^{17}$ Dari pengertian yang diberikan mengenai nominee tersebut dapat diketahui bahwa secara harfiah, nominee, mempunyai dua arti yang berbeda. Pertama, nominee merujuk pada suatu usulan, atau nominasi kandidat atau calon untuk menduduki suatu jabatan tertentu, untuk memperoleh suatu penghargaan tertentu, atau untuk jenis-jenis pencalonan lainnya. Kedua, nominee memberikan pengertian sebagai seseorang yang mewakili kepentingan pihak lain. Dalam pengertian yang kedua ini, seorang nominee dibedakan dari seorang pemberi kuasa dalam keadaan; dimana nominee menjadi pemilik dari suatu benda (termasuk kepentingan atau hak yang lahir dari suatu perikatan) yang berada dalam pengurusannya; sedangkan penerima kuasa tidak pernah

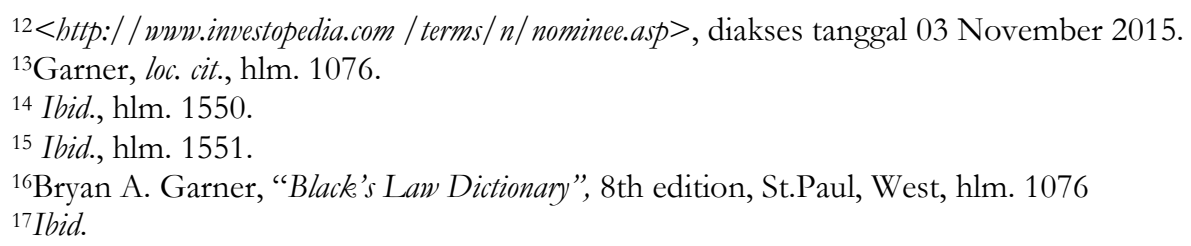


menjadi pemilik dari benda (termasuk kepentingan) yang diurus oleh nominee ini. ${ }^{18}$

Pihak yang menunjuk nominee seringkali dikenal sebagai pihak beneficiary. Nominee mewakili kepentingan-kepentingan dari beneficiary dan karenanya nominee dalam melakukan tindakan-tindakan khusus harus sesuai dengan yang diperjanjikan dan tentunya harus sesuai dengan perintah yang diberikan oleh pihak beneficiary.

Dengan melihat seluruh pengertian di atas, maka dapat diketahui bahwa dalam konsep nominee dikenal dua pihak, yaitu pihak nominee yang tercatat secara hukum dan pihak beneficiary yang menikmati setiap keuntungan dan kemanfaatan dari tindakan-tindakan yang dilakukan oleh pihak yang tercatat secara hukum. Terdapatnya dua pihak dalam nominee agreement melahirkan dua jenis kepemilikan, yaitu pemilik yang tercatat dan diakui secara hukum (legal owner/juridische eigendom) dan pemilik yang sebenarnya (beneficial owner/economische eigendom) menikmati keuntungan berikut kerugian yang timbul dari benda yang dimiliki oleh nominee. ${ }^{19}$

Secara de jure, nominee adalah pemegang hak yang sah atas benda tersebut, yang tentunya memiliki hak untuk mengalihkan, menjual, membebani, menjaminkan serta melakukan tindakan apapun atas benda yang bersangkutan, sedangkan pihak beneficiary secara de facto tidak diakui sebagai pemilik atas benda secara hukum. Pada dasarnya pembentukan suatu nominee dapat dilakukan dengan 2 cara, yaitu:

\section{Nominee Langsung (direct nominee)}

Pembentukan nominee secara langsung dibentuk dengan cara membuat dan menandatangani nominee agreement antara beneficiary dan nominee dalam satu perjanjian. Di dalam perjanjian tersebut diatur secara tegas dan jelas mengenai

${ }^{18}$ Gunawan Widjaja, "Nominee Shareholders Dalam Perspektif UUPT Baru dan UU Penanaman Modal Baru Serta Permasalahannya Dalam Praktik" dalam Jurnal Hukum dan Pasar Modal Volume III Edisi 4, AgustusDesember 2008, hlm 43.

${ }^{19}$ Konsep Juridische Eigendom dan Economische Eigendom dahulu berkembang di Indonesia dengan maraknya produk Reksa Dana berberntuk KIK yang dikenal dengan sebutan Unit Penyertaan. Lebih lanjut dalam Nindyo Pramono, Hukum PT Go Public dan Pasar Modal, ANDI Yogyakarta, Yogyakarta, 2013, hlm. 395. Lihat juga Gunawan Widjaja, Transplantasi Trust dalam KUHPerdata, KUHD dan Undang-Undang Pasar Modal Indonesia, PT Raja Grafindopersada, Jakarta, 2008, hlm. 6, dikatakan, "Ketentuan Pasal 56 ayat (1), (2) dan ayat (3) UU Pasar Modal mengatur mengenai penitipan kolektifyang memisahkan kepemilikan tedaftar (registered ownership) dan kepemilikan manfaat (beneficial ownership)." 
pemberian kepercayaan dan kewenangan dari beneficiary kepada nominee untuk melakukan kegiatan atau bisnis tertentu atas perintah dan kepentingan beneficiary.

Dalam kepemilikan saham oleh pihak asing yang menggunakan konsep nominee, pada umumnya nama dan identitas dari pihak yang tercatat sebagai pemilik sah dalam daftar pemegang saham perusahaan hanya nama dan identitas diri dari pihak nominee. Nama dan identitas diri dari pihak beneficiary tidak muncul dalam bentuk apapun juga dalam daftar pemegang saham perusahaan. Dengan digunakannya nama serta identitas dari nominee sebagai pihak yang tercatat secara hukum, maka pihak beneficiary memberikan kompensasi dalam bentuk nominee fee. Jumlah dari nominee fee tersebut berdasarkan kesepakatan bersama antara nominee dan beneficiary. Setelah tercapainya kesepakatan bersama, maka jumlah dan tata cara pembayaran dari nominee fee akan dituangkan dalam bentuk suatu perjanjian tertulis yang ditandatangani oleh nominee dan beneficiary sebagai suatu bentuk persetujuan.

Adapun karakteristik atau ciri-ciri penggunaan konsep nominee saham antara lain: a. terdapatnya 2 jenis kepemilikan yaitu kepemilikan secara hukum (juridische eigendom) dan secara manfaat (economische eigendom); b. nama dan identitas nominee akan didaftarkan sebagai pemilik dari saham di Daftar Pemegang Saham perusahaan dalam kepemilikan saham oleh nominee; c. pihak nominee menerima fee dalam jumlah tertentu sebagai kompensasi penggunaan nama dan identitas dirinya untuk kepentingan beneficiary.

Dengan demikian, dapat dilihat bahwa struktur yang digunakan dalam konsep nominee adalah terdapatnya perjanjian yang dibuat oleh dan antara nominee dengan beneficiary, yang dikenal dengan nama nominee agreement. Nominee dan beneficiary akan menentukan hal-hal apa saja yang akan dituangkan dalam nominee agreement tersebut. Dalam perjanjian tersebut selain mengatur mengenai jumlah dan tata cara pembayaran nominee fee, juga akan mengatur mengenai ketentuanketentuan yang mewajibkan dan/atau melarang nominee untuk melakukan sesuatu hal yang berkaitan dengan penggunaan konsep nominee.

\section{Nominee Tidak Langsung (undirect nominee)}

Nominee ini tidak dibentuk dari nominee agreement yang secara tegas dan jelas memberikan kepercayaan dan kewenangan dari beneficiary kepada nominee. 
Nominee tidak langsung tidak dibuat hanya terdiri dari satu perjanjian saja, melainkan terdiri dari beberapa perjanjian yang apabila dihubungkan satu sama lain akan menghasilkan nominee saham. Beneficiary dapat mengendalikan nominee untuk melakukan tindakan atau kegiatan bisnis tertentu atas perintah dan kepentingan beneficiary.

Adapun akta-akta yang dibuat baik secara notaril maupun di bawah tangan adalah sebagai berikut: a. Akta Perjanjian Kredit (Loan Agreement); b. Perjanjian Gadai Saham (Pledge of Share Agreement); c. Perjanjian Penggantian Kerugian (Indemnity Agreement); d. Surat Kuasa Untuk Bersuara (Power of Attorney to Vote); e. Perjanjian Jual Beli Saham dan Kuasa Menjual (Sale And Purchase of and Attorney to Sell Shares).

Apabila dilihat dari akta-akta tersebut maka dapat disimpulkan bahwa nominee sebagai pemegang saham sebenarnya di dalam hukum tidak mempunyai kewenangan dalam melaksanakan hak-hak yang melekat atas saham-saham yang dipegangnya dalam perseroan terbatas karena telah diserahkan kepada beneficiary. Namun pada kenyataannya secara yuridis formal pemegang saham nominee yang bewenang melaksanakan hak-hak atas saham yang dipegangnya.

Menurut hemat peneliti, pembentukan nominee agreement baik yang melalui pembentukan nominee langsung maupun nominee tidak langsung mempunyai tujuan atau prestasi yang sama untuk menghasilkan nominee saham di Indonesia. Tujuan atau prestasi yang ingin dicapai adalah: a. beneficiary sebagai pengendali dari saham dan nominee adalah sebagai pemilik terdaftar; b. sumber dana yang digunakan berasal dari beneficiary namun dibuat seolah-olah merupakan pinjaman beneficiary kepada nominee; c. hak atas saham yang dimiliki oleh nominee menjadi hilang, sehingga beneficiary yang mempunyai hak untuk menjual, mentransfer, mengalihkan saham tersebut; d. beneficiary menerima manfaat dari saham tersebut berupa deviden maupun keuntungan lainnya.

\section{Kedudukan Nominee Agreement dalam Aturan Hukum di Indonesia}

Konsep nominee tidak mendapatkan pengakuan dalam sistem hukum di Indonesia, khususnya dalam nominee shareholder pada badan hukum Perseroan 
Terbatas. Konsep kepemilikan saham yang dianut dalam UUPT merupakan kepemilikan saham mutlak (dominium plenum). ${ }^{20}$ Konsep Dominium Plenum tercermin dalam Pasal 52 ayat (2) UUPT yang menyatakan bahwa "Setiap saham memberikan kepada pemilikinya hak yang tidak dapat dibagi". Namun pada kenyataannya, nominee shareholder tetap masih digunakan para investor asing untuk berinvestasi secara langsung dengan membuat nominee agreement.

Seiring dengan berjalannya waktu, pembentukannya pun mengalami perkembangan mulai dari nominee yang dibuat langsung hingga nominee agreement yang dibuat sacara tidak langsung demi menyembunyikan atau menyamarkan perjanjian nominee tersebut. Praktek pembentukan nominee tidak langsung sendiri mulai marak digunakan ketika diundangkannya UUPM yang melarang melakukan penanaman modal dalam bentuk perseroan terbatas dilarang membuat perjanjian dan/atau pernyataan yang menegaskan bahwa kepemilikan saham dalam perseroan terbatas untuk dan atas nama orang lain.

Pelaksanaan nominee agreement di Indonesia seperti yang telah dijelaskan di atas, menemui beberapa kendala. Pelanggaran terhadap syarat obyektif dalam Pasal 1320 KUHPerdata mengenai sebab yang halal dan penjabarannya mengenai sebab yang halal dalam Pasal 1337 KUHPerdata bahwa nominee agreement tidak boleh bertentangan dengan undang-undang menjadi alasan nominee saham di Indonesia tidak dapat dituntut pemenuhannya atau pelaksanaannya dihadapan hukum. Hal ini dikarenakan saham bertentangan dengan Pasal 52 ayat (4) UUPT mengenai konsep kepemilikan saham secara dominium plenum, serta salah satu syarat pendirian perseroan terbatas yang terdiri dari dua) orang atau lebih dalam arti terdapat 2 pemegang saham atau lebih pada Pasal 7 ayat (1) UUPT menjadi bertentangan apabila prestasi yang diinginkan para pihak dalam nominee agreement untuk memiliki saham dalam perseroan sebesar 100\%.

Pelaksanaan gadai saham dalam rangka mendukung praktek nominee saham juga mengalami kendala dalam hal ini bertentangan dengan prinsip pengalihan manfaat dalam gadai seperti yang telah dijelaskan pada bagian terdahulu. Dalam UUPT menganut konsep dominium plenum yang berarti bahwa saham adalah

${ }^{20}$ Indonesian, Loc. Cit., Lihat Pasal 52 ayat (4) UUPT 
sebagai suatu unitas yang mengajarkan bahwa saham dari suatu PT merupakan satu kesatuan yang utuh. Doktrin ini dengan tegas terdapat pada Pasal 52 ayat (4) UUPT yang akan menyebutkan bahwa setiap saham memberikan hak kepada pemilik hak yang tidak dapat dibagi-bagi. Itulah sebabnya maka dalam perjanjian gadai saham, dengan ditentukan hak suara tetap berada pada pemegang saham, bukan pada pihak penerima gadai sebagaimana diatur dalam Pasal 60 ayat (4) UUPT.

Dengan demikian pelaksanaan perjanjian nominee yang dibentuk secara langsung dengan nominee agreement adalah batal demi hukum. Untuk pembentukan nominee langsung, dalam peraturan perundang-undangan di Indonesia pada dasarnya dilarang. Sesuai dengan Pasal 33 ayat (1) dan (2) UUPM yang menyebutkan bahwa:

“(1) Penanam modal dalam negeri dan penanam modal asing yang melakukan penanaman modal dalam bentuk perseroan terbatas dilarang membuat perjanjian dan/atau pernyataan yang menegaskan bahwa kepemilikan saham dalam perseroan terbatas untuk dan atas nama orang lain.

(2) Dalam hal penanam modal dalam negeri dan penanam modal asing membuat perjanjian dan/atau pernyataan sebagaimana dimaksud pada ayat (1), perjanjian dan/atau pernyataan itu dinyatakan batal demi hukum."

Akan tetapi dalam pembentukan nominee tidak langsung tidak ada satupun akta-akta atau dokumen yang menyatakan bahwa kepemilikan saham dalam perseroan terbatas untuk dan atas nama orang lain sehingga sebenarnya secara formal perjanjian-perjanjian tersebut tidak melanggar Pasal 33 ayat (1) dan (2) UUPM serta syarat objektif menurut Pasal 1320 KUHPerdata akan tetapi secara material ada kehendak yang tidak sesuai dengan pernyataan. Dengan kata lain, jika seseorang dengan sadar mengusulkan tindakan hukum yang tidak sesuai dengan kenyataannya maka terjadilah simulasi. Suatu perjanjian yang mengatur segala sesuatu hal yang berbeda dengan keadaan sebenarnya untuk suatu tujuan tertentu dikenal dengan istilah simulasi yang berasal dari kata simulation, simulated contract, ostensible action (Inggris); schijnhandeling (Belanda); simulatio (Latin).

Parameter untuk menentukan suatu perjanjian termasuk perjanjian simulasi atau perjanjian pura-pura didasarkan pada tatanan peraturan perundangundangan atau prinsip hukum sebagai kriterium kebenaran koheren yaitu: 1. Pasal 1873 KUHPerdata yang menyebutkan bahwa: "Persetujuan lebih lanjut, yang 
dibuat dalam suatu akta tersendiri (yang bertentangan dengan akta asli, hanya memberikan bukti diantara para pihak, para ahli waris atau penerima hak, tetapi tidak dapat berlaku terhadap orang-orang pihak ketiga yang beritikad baik. 2. Pasal 1320 KUHPerdata menyatakan bahwa untuk sahnya suatu perjanjian harus memenuhi 4 syarat diantaranya syarat adanya kausa yang halal. Undang-undang tidak menjelaskan apa yang dimaksud dengan kausa yang halal dan hanya menjabarkan lebih lanjut dalam Pasal 1335 dan 1337 KUHPer. Pasal 1335 KUHPerdata, berbunyi: "Suatu persetujuan tanpa sebab atau yang telah dibuat karena suatu sebab yang palsu atau terlarang, tidak mempunyai kekuataan." Pasal 1337 KUHPerdata, berbunyi: "Suatu sebab adalah terlarang, apabila dilarang oleh undang-undang atau apabila berlawanan dengan atau ketertiban umum".

KUHPerdata mengenal adanya 3 macam kausa, yaitu: a. perjanjian tanpa kausa adalah perjanjian tanpa tujuan atau sebab dan perjanjian tanpa kausa bukan termasuk kausa yang terlarang maupun kausa yang palsu. Perjanjian tanpa kausa suatu perjanjian yang dituju oleh para pihak tidak mungkin untuk dilaksanakan. Contoh perjanjian tanpa kausa yaitu:21 Perjanjian novasi yang maksudnya adalah untuk menggantikan perikatan lama dengan perikatan baru. Jika perikatan lama yang akan diganti tidak ada, maka perjanjian novasi adalah batal; b. perjanjian dengan kausa yang palsu. Maksud suatu perjanjian memang mengandung kausa tetapi bukan kausa yang sebenarnya. Kausa yang palsu, yang bukan kausa yang sebenarnya, dapat merupakan yang terlarang atau yang bertentangan dengan undang-undang, ketertiban umum atau kesusilaan dan bisa juga yang palsu itu bukan merupakan kausa yang terlarang. ${ }^{22}$ c. perjanjian dengan kausa terlarang. Perjanjian dengan kausa yang terlarang maksudnya adalah suatu perjanjian yang bertentangan dengan undang-undang, kesusilaan dan ketertiban umum.

Perjanjian yang terlarang oleh undang-undang dapat ditinjau dari 3 aspek yaitu substansi perjanjian yang terlarang oleh undang-undang, pelaksanaan perjanjian yang dilarang oleh undang-undang dan motivasi atau maksud dan tujuan membuat perjanjian yang dilarang oleh undang-undang. ${ }^{23} 3$. Kata sepakat

${ }^{21}$ J. Satrio, Hukum Perjanjian, Citra Aditya Bakti, Bandung, 1992, hlm. 322-333.

${ }^{22}$ Ibid., hlm. 326-329.

${ }^{23}$ Herlien Budiono, Op. Cit., hlm. 89 
merupakan essensialia atau unsur yang mutlak ada dalam lahirnya atau terbentuknya suatu perjanjian sebagaimana dimaksud dalam Pasal 1320 KUHPerdata. Kata sepakat menjadi persesuaian antara kehendak dan pernyataan. Herlien Budiono mengatakan kehendak dimaksudkan sebagai kehendak yang dinyatakan dan ditujukan untuk timbulnya akibat hukum. Pada umumnya pernyataan yang diberikan seseorang adalah sesuai dengan kehendak, namun juga terbuka kemungkinan ada kesesuaian antara kehendak dan pernyataan, dan hal ini terjadi dalam hal pernyataan yang diinginkn sesuai dengan yang dimaksud oleh pihak lawan, tetapi akibat hukumnya tidak diinginkan. ${ }^{24}$

Sehingga jika dilihat dari tujuan perjanjian-perjanjian nominee tidak langsung atau perjanjian simulasi tersebut diatas, secara normatif perjanjian-perjanjian tersebut adalah batal demi hukum. Karena perjanjian-perjanjian yang dibuat untuk membentuk nominee agreement yang tidak langsung (undirect nominee) merupakan perjanjian-perjanjian dengan kausa palsu yang bertentangan dengan undang-undang. Syarat objektif kausa yang halal sesuai Pasal 1320 KUHPerdata tidak terpenuhi. Penafsiran kausa yang halal secara luas tidak hanya melihat substansi yang secara eksplisit tertuang perjanjian, melainkan motivasi atau maksud dan tujuan membuat perjanjian yang dilarang oleh undang-undang yang dalam hal ini adalah Pasal 33 ayat (1) dan (2) UUPM. Sehingga, permasalahannya adalah untuk mengidentifikasi dan membuktikan apakah suatu perjanjian tersebut merupakan simulasi atau bukan. Dalam pembentukan perjanjian nominee tidak langsung, perjanjian yang digunakan adalah perjanjian yang tidak melanggar peraturan perundang-undangan. Dari sisi nominee, kerugian yang ditimbulkan sebagai akibat dari keputusan yang dibuat oleh beneficiary dalam pengurusan saham, mengeluarkan suara dalam RUPS maupun akibat-akibat hukum lainnya yang timbul dari keputusan tersebut, di hadapan hukum nominee sebagai pihak yang bertanggung jawab. Hal ini karena nominee sebagai pemilik sah menurut hukum atas saham tersebut. Tanggung jawab beneficiary untuk menanggung kerugian yang diderita nominee tidak dapat dipaksakan dihadapan hukum. Pada pihak beneficiary, apabila nominee tidak mau menyerahkan saham 
yang dipegangnya kepada beneficiary maka beneficiary harus melakukan upaya hukum dengan melakukan gugatan perdata di pengadilan.

Hal yang demikian, nominee agreement khususnya untuk nominee tidak langsung menimbulkan ketidak kepastian hukum, karena secara normatif perjanjianperjanjian nominee tersebut adalah batal demi hukum. Perjanjian-perjanjian tersebut di hadapan hukum tetap diakui, namun terdapat kesulitan dalam hal pembuktian di pengadilan karena kebanyakan perjanjian-perjanjian tersebut dibuat dengan akta notaris sehingga menjadi alat bukti yang sempurna. Dalam sistem peradilan perdata hakim lebih melihat kebenaran formal dari pada kebenaran material. Meskipun hakim mempunyai keyakinan bahwa serangkaian perjanjian-perjanjian tersebut merupakan perjanjian simulasi atau nominee agreement, hakim tidak bisa serta merta dapat membatalkan perjanjian tersebut kecuali dapat dibuktikan bahwa ada kausa yang terlarang dalam perjanjian-perjanjian tersebut.

\section{Penutup}

Berdasarkan uraian diatas, diperoleh kesimpulan sebagai berikut: pertama, nominee agreement telah tumbuh dan berkembang di masyarakat, dikarenakan kebutuhan masyarakat. Pembentukan nominee agreement dalam prakteknya dapat dibedakan menjadi pembentukan perjanjian nominee langsung (direct nominee) yakni dengan secara langsung membuat perjanjian antara yang menegaskan bahwa kepemilikan saham dalam perseroan terbatas untuk dan atas nama orang lain dan pembentukan nominee tidak langsung (undirect nominee) yakni dengan cara membuat beberapa perjanjian yang berlapis-lapis dengan tujuan agar beneficiary dapat mengendalikan, menerima manfaat dan secara tidak langsung memiliki dari saham tersebut. Kedua, kedudukan nominee agreement dalam aturan hukum di Indonesia sebenarnya telah dilarang eksistensinya dalam Pasal 33 ayat (1) dan (2) UUPM. Tidak adanya pelarangan yang tegas dalam UUPT tentang pelarangan nominee shareholder membuat praktek nominee agreement berkembang dengan pembentukan nominee dengan nominee tidak langsung atau perjanjian simulasi yang menyebabkan nominee tersebut sulit untuk diketahui dan dibuktikan. 


\section{Daftar Pustaka}

Gogna, P.P.S., A Textbook of Company Law, Ram Nagar, S. Chand \& Company Ltd., New Delhi, 2009.

Kairupan, David, Aspek Hukum Penanaman Modal Asing di Indonesia, Kencana Prenada Media Group, Jakarta, 2013.

Keraf, A. Sonny, \&Mikhael Dua, Ilmu Pengetahuan, Sebuah Tinjauan Filosofis, Yogyakarta, 2001.

Margono, Sujud, Hukum Investasi Asing di Indonesia, Novindo Pustaka Mandiri, Jakarta, 2008.

Notodisoerjo, Soegondo, Hukum Notariat di Indonesia, Suatu Penjelasan, Rajawali, Jakarta, 1982.

Pramono, Nindyo, Bunga Rampai Hukum Bisnis Aktual, Citra Aditya Bakti, Bandung, 2006.

Hukum PT Go Public dan Pasar Modal, ANDI Yogyakarta, Yogyakarta, 2013.

Satrio, J., Hukum Perjanjian, Citra Aditya Bakti, Bandung, 1992.

Sedarmayanti \& Syarifudin Hidayat, Metodologi Penelitian, Mandar Maju, Bandung, 2002.

Subekti, Pokok-Pokok Hukum Perdata, cet.27, Intermasa, Jakarta, 1995.

Widjaja, Gunawan, “Transplantasi trust dalam KUHPerdata, KUHD dan UndangUndang Pasar Modal Indonesia", PT Raja Grafindopersada, Jakarta, 2008.

Widjaya, I.G. Rai, Hukum Perusahaan (Undang-Undang dan Peraturan Pelaksana Undang-Undang di Bidang Usaha), Kesaint Blanc, Bekasi, 2005.

Yani, Ahmad, \& Gunawan Widjaja, Seri Hukum Perseroan Terbatas, Cet. ketiga, Raja Gafindo, Jakarta, 2003.

KUHPerdata

Undang-Undang Nomor 02 Tahun 2014 tentang Perubahan atas Undang-Undang Nomor 39 Tahun 2004 tentang Jabatan Notaris (Lembaran Negara Republik Indonesia No. 03 Tahun 2014, Tambahan Lembaran Negara Republik Indonesia No. 5491).

Undang-Undang Nomor 40 Tahun 2007 tentang Peseroan Terbatas (Lembaran Negara Republik Indonesia No. 106 Tahun 2007, Tambahan Lembaran Negara Republik Indonesia No. 4756).

Undang-Undang Nomor 25 Tahun 2007 tentang Penanaman Modal (Lembaran Negara Republik Indonesia No. 101 Tahun 2007, Tambahan Lembaran Negara Republik Indonesia No. 4724).

Undang-Undang No. 30 Tahun 2004 tentang Jabatan Notaris, Lembaran Negara Republik Indonesia No.117, Tambahan Lembaran Negara Republik Indonesia No. 4432). 
Gunawan Widjaja, “Nominee Shareholders Dalam Perspektif UUPT Baru dan UU Penanaman Modal Baru Serta Permasalahannya Dalam Praktik" dalam Jurnal Hukum dan Pasar Modal (Volume III Edisi 4, Agustus-Desember 2008). "Pentingnya Pengaturan Trust dalam Institusi di luar Pasar Modal", Ed.18, Buletin Himpunan Konsultan Hukum Pasar Modal, Jakarta, 2013. 